\title{
$\mathrm{ESCO}$ 에너지절약 성과보증의 $\mathrm{M \& V}$ 적용사례 분석
}

\author{
임기추
}

에너지경제연구원

(2014년 5월 17일 접수, 2014년 6월 19일 수정, 2014년 6월 20일 채택)

\section{A Survey on the $M \& V$ to guarantee the energy saving performance of ESCO}

\author{
Ki Choo, Lim
}

Korea Hydro \& Nuclear Power Co.

(Received 17 May 2014, Revised 19 June 2014, Accepted 20 June 2014)

요약

$\mathrm{ESCO}$ 업계는 2013년 $\mathrm{ESCO}$ 규정의 개정으로 에너지절약성과 보증계약에 대한 역량을 강화하여야 한다. 이러한 시점에서 에너지절약성과에 대한 측정 - 검증 $(\mathrm{M} \& \mathrm{~V})$ 이 중요한 과제로 부각되고 있다. 이에 따라, 선진국의 $\mathrm{M \& V}$ 적용사례 파악이 필요하다. 에너지사용자와 $\mathrm{ESCO}$ 기업 간의 에너지절약성 과 보증계약 체결에 의한 에너지절약설치로 발생되는 에너지절감량을 측정 - 평가하는 방안을 제공하는 것이 무엇보다 중요하다고 할 수 있다. 2013년부터 성과보증계약 방식 위주의 ESCO 사업이 추진되기 시작하였다. 따라서 이러한 이유로 IPMVP에서 권고하고 미국이나 일본에서 적용하고 있는 M\&V 사례 를 활용하여 우리나라의 $\mathrm{ESCO}$ 여건에 적합한 $\mathrm{M \& V}$ 적용방안의 마련이 필요한 것으로 판단된다

주요어 : $\mathrm{ESCO}$, 성과보증, 측정 · 검증 $(\mathrm{M} \& \mathrm{~V})$

Abstract - ESCO industry should guarantee the energy saving performance in response to changes of regulations ESCO. In this point, the application of the M\&V is important task on energy saving performance. Therefore, we need to examine the contents of practice for the $\mathrm{M} \& \mathrm{~V}$ in developed countries. Between energy user and $\mathrm{ESCO}$, it is important to provide and measure the energy saving performance by guarantee of energy savings performance contracts. After 2013 ESCO business began focusing on guaranteed savings contracts. For this reason, we need to take $\mathrm{M} \& \mathrm{~V}$ cases recommended from IPMVP and applied in United States and Japan. Therefore, we should be ready about M\&V application for the real conditions of ESCO.

Key words : ESCO, guaranteed savings contracts, measurement \& verification(M\&V)

\section{1. 서 론}

정부는 $\mathrm{ESCO}$ 산업의 시장확대 및 활성화 촉진방 안의 일환으로 기존 성과배분계약과 성과보증계약의 장점을 결합한 사업자파이낸싱 성과보증계약 방식을 시행하고 있다 [1,2]. 기존 성과배분방식이 2013년부

\footnotetext{
${ }^{\dagger}$ To whom corresponding should be addressed.

Korea Energy Economics Institute, Uiwang 437-713, Korea

Tel : 031-420-2295 E-mail : kclim@keei.re.kr
}

터 퇴출됨에 따라 이제 $\mathrm{ESCO}$ 사업은 사업자 및 사 용자파이낸싱 성과보증계약과 같은 성과보증계약 방 식으로 재편되고 있기 때문에, $\mathrm{ESCO}$ 의 에너지절약 성과에 대한 측정·검증(Measurement, Verification, $\mathrm{M \& V}$ )이 중요한 과제로 부각되고 있다.

우리나라에서는 $\mathrm{ESCO}$ 에 대한 정책자금이 지원됨 에 따라 $\mathrm{ESCO}$ 규정 및 $\mathrm{ESCO}$ 정책자금 추천심사 시 $\mathrm{M} \& \mathrm{~V}$ 에 대한 평가항목이 설정되어 있으므로, 이에 관한 계획서와 결과서를 제출해야 되는 상황이다 [2]. 
$\mathrm{M} \& \mathrm{~V}$ 는 $\mathrm{ESCO}$ 사업 성과보증계약의 필수 요소이며, 성과보증계약은 선진국형 방식으로 에너지사용자가 금융기관을 통해 절약시설 투자에 따른 자금을 조달 하고, $\mathrm{ESCO}$ 업체는 기술적인 부분에서 성과를 보장 하는 방식이다. $\mathrm{M} \& \mathrm{~V}$ 란 에너지절감 프로젝트에서 합 의된 구체적인 에너지성능 측정 및 검증방안을 기준 으로 에너지절감량을 측정하고 검증해 가는 절차라 할 수 있다.

해외에서는 이미 성과보증계약 방식 위주의 $\mathrm{ESCO}$ 사업이 정착되었기 때문에 $\mathrm{M} \& \mathrm{~V}$ 가이드라인을 개발 및 활용하는 것이 보편화되고 있는 상황이다 $[4,6,7]$. 따라서 $\mathrm{ESCO}$ 기업에 대한 성과보증계약 방식 위주 의 사업을 활성화하는 측면에서 선진국에서 보편적으 로 활용하고 있는 $\mathrm{M \& V}$ 사례 파악이 요청된다.

이에 본고에서는 먼저 2절에서 IPMVP(국제성능측 정·검증의정서)의 발간배경 및 주요내용, 3절에서는 미 국 에너지관리프로그램의 $\mathrm{M} \& \mathrm{~V}$ 변화 및 주요내용, 4절 에서 일본 에너지절약성과 $\mathrm{M} \& \mathrm{~V}$ 가이드라인의 주요내 용을 소개하고 5절에서 시사점을 제시하고자 한다.

\section{IPMVP 가이드라인의 주요내용}

\section{2-1. IPMVP의 발간배경 [5,6]}

1996년 미국 주도로 에너지절약성과 M\&V에 관한 최초 북미에너지관리 $\mathrm{M} \& \mathrm{~V}$ 가이드라인(North American Energy Measurement and Verification Protocol, NEMVP)이 공표되었다. 이는 건물에 대한 에너지절약 개보수를 실시할 때 개보수에 의한 에너 지절약성과를 정확하게 파악하기 위해 $\mathrm{M} \& \mathrm{~V}$ 의 실행 이 필요한 계기로 시작된 것이다. 그 후 12 개국에서 20 여명의 전문가에 의해 1997 년에 국제성능측정.검 증의정서(International Performance Measurement and Verfication Protocol, IPMVP)로 공표되었다.

IPMVP는 미국 내에서는 물론 국제적인 보급을 추 진해 왔으며, 현재까지 13 개국의 언어로 번역되어 공 표되고 있다. 즉 불가리아, 중국, 체코, 일본, 한국, 폴 란드, 포르투갈, 루마니아, 러시아, 스페인, 우크라이 나 등이다. 2002년에는 IPMVP의 개정 보완을 위해 16 개국의 정부기관 직원, 25 개국의 100 명 이상의 전 문가가 참여한 작업과정을 통해 발간되었다. 2007년 4 월에는 $\mathrm{M} \& \mathrm{~V}$ 개념, 에너지절약관련 보고, 에너지절 약량 산출 등에 관한 내용 추가 및 전반적인 내용을 보완하여 IPMVP의 개정판이 발간되기에 이르렀다.

\section{2-2. IPMVP의 역할 [6]}

IPMVP의 주요역할은 에너지절약 개보수를 실시 하는 고객사업자융자 등의 관계자에 대해 프로젝트 의 $\mathrm{M} \& \mathrm{~V}$ 에 대한 검토 시 정보 제공, 시설 전체의 에 너지절약량 및 개별 대책에 따른 에너지절약량을 파 악하기 위한 방법 제공, 업무시설·제조시설. 주택의 에 너지절약 개보수 등 여러 종류의 건물에 대한 적용이 가능하고, 특정지역 뿐만 아니라 국제적 활용이 가능 하도록 $\mathrm{M \& V}$ 방법에 대해서 정확도나 비용의 차이 정도에 따라 복수의 방법을 제시하였다.

가이드라인의 이용 대상자는 시설의 에너지관리자, 프로젝트의 수행자, $\mathrm{ESCO}$ 사업자, $\mathrm{NGO}$, 재무관계 자, 금융기관, 컨설턴트 및 정부의 시책 제안 및 실행 자 등이 될 수 있다.

\section{2-3. IPMVP의 M\&V 방법 개요 [6]}

2007년에 개정된 IPMVP의 주요내용을 보면 1) IPMVP의 개요, 2) $\mathrm{M} \& \mathrm{~V}$ 개념.목적·원리, 3) 옵션 (option, $\mathrm{M} \& \mathrm{~V}$ 방법)별 $\mathrm{M} \& \mathrm{~V}$ 방법의 개요, 4) 일반 적인 과제, 5) 측정에 관한 과제, 6) 옵션별 적용사례 등을 수록하고 있다.

에너지절약량의 산정은 일반적으로 개선 전의 기 준년도 에너지소비량과 개선 후의 에너지소비량의 비 교에 의해 산출된다.

에너지절약량 $=$ 기준년도 에너지소비량 - 개선 후 에너지소비량 \pm 보정치

여기서, 보정치는 기준년도의 에너지소비량과 개선 후의 에너지소비량의 계산조건과 같은 요인을 고려한 다. 보정요인으로는 기후변화, 산업용에 대한 근무시 간대 야간 전환의 추가, 임대점유율의 증가, 전력이용 소비기기의 증가 등이 있다.

$\mathrm{M} \& \mathrm{~V}$ 의 순서는 $\mathrm{M} \& \mathrm{~V}$ 옵션 선택을 시작으로 $\mathrm{M} \& \mathrm{~V}$ 계획에 따른 분석 및 보고서 작성에 이르는 절 차로 진행된다. 먼저, 1) IPMVP의 M\&V 옵션을 선 택, 2) 에너지소비량에 관련된 변수 등의 데이터를 수 집, 3) 에너지절약 계획 수립, 4) 에너지절약 대책별 로 $\mathrm{M} \& \mathrm{~V}$ 계획을 결정, 5) 에너지절약대책에 대한 설 계 및 시공을 실시, 6) 에너지절약대책을 모두 실시 한 이후에는 설비 및 시스템의 성능 확보상황을 확인, 7) 에너지절약 개선후의 에너지소비 데이터, 변수 데 이터를 수집, 8$) \mathrm{M \& V}$ 계획에 따른 분석 및 보고서 
를 작성하게 된다. 다만, 성과계약 등에 의한 에너지 절약 보고서를 정기적으로 제출하는 경우 7)과 8)을 반복 실시하게 된다.

\section{2-4. $\mathrm{M} \& \mathrm{~V}$ 계획의 포함항목 [6]}

IPMVP의 $\mathrm{M} \& \mathrm{~V}$ 계획에 포함하는 주요내용을 요 약하면, 1) 에너지절약 대책의 개요와 도입에 의한 성 과, 2) 에너지절약성과의 계산범위 확인(대책 도입범 위에 대한 한정 또는 시설전체 여부 확인), 3) 시설현 황 및 베이스라인 에너지소비량, 4) 기준년도 이후 미 리 알고 있는 상황의 변화 확인(예, 야간의 설정온도 의 변경 등), 5) 에너지절약 개선후의 기간확인(의뢰 계약기간 및 성과 계약기간 등), 6) 모든 에너지절약 기기가 정상적으로 설치되었는지를 확인, 7) 에너지 절약 대책의 설계, 측정 순서의 문서화, 8$) \mathrm{M} \& \mathrm{~V}$ 에 사용되는 옵션종류, 9) 정확한 데이터분석의 순서, 알 고리즘, 추계방법의 개요, 10 ) 측정 장소, 측정기간, 측정기의 사양, 측정기 이용분석 프로토콜, 성능보장 의 순서, 측정기의 보정방법, 결측 데이터의 취급사 항, 11) 품질보증의 순서, 12) 측정치, 데이터수집, 해 석의 정확도, 13) 결과의 보고·문서화의 방법, 14) 보 고된 절감량에 대한 다른 단체 등에 의한 별도의 실 증시 데이터에 대한 사양, 15) 예측되는 변동요인에 대한 베이스라인의 보정방법, 16) 예산에너지절약성 과 산정시 필요 항목확인(초기 설치비용, 개선 후 운 영비용 포함) 등으로 설명하고 있다.

2-5. $\mathrm{M} \& \mathrm{~V}$ 옵션 [6]

IPMVP에서는 4 종류의 $\mathrm{M} \& \mathrm{~V}$ 방법을 소개하고
있다. 옵션 $\mathrm{A}$ 는 부분 측정, 기기별 측정에 대해 설명 하고 있으며, 옵션 $\mathrm{B}$ 는 기기별 측정, 옵션 $\mathrm{C}$ 는 시설 전체의 측정, 옵션 $\mathrm{D}$ 는 시뮬레이션에 의한 보정하는 등의 적용하는 방법을 소개하고 있다.

\section{3. 미국 에너지관리프로그램 $\mathrm{M} \& \mathrm{~V}$ 가이드라인의 주요내용}

3-1. 미국 $\mathrm{ESCO}$ 모니터링 및 $\mathrm{M \& V}$ 의 변천과정 [4,7,8]

미국에서는 에너지절약성과에 대한 $\mathrm{M} \& \mathrm{~V}$ 방법에 대해서 1994년부터 에너지부(DOE)가 업계와 공동으 로 가이드라인을 검토하기 시작하였다. 그 후 1996년 $\mathrm{M} \& \mathrm{~V}$ 가이드라인을 처음 개발 및 1997년 IPMVP의 개발을 계기로, $\mathrm{ESCO}$ 사업에 대한 에너지성과계약 (EPC) 계약이 정착되는 전환점으로 작용한 것으로 평가된다. 1985년 이전 모니터링 및 검증 또는 $\mathrm{M} \& \mathrm{~V}$ 시스템은 초기 전력회사 수요관리(DSM) 프로그램의 진행상황을 추적하는 데 사용되었으며, 측정활동 보 다 성과활동(예, $\mathrm{kWh}$ )을 주력하는 시기이다. 1985 1993 년 기간 중에는 $\mathrm{ESCO}$ 와 고객이 익숙하지 않은 기술에 대한 $\mathrm{M} \& \mathrm{~V}$ 시스템을 개발하기 위해 노력한 시기로, $\mathrm{ESCO}$ 기업이 보통 고객의 위험을 완화하는 “성과배분” 계약서를 사용하는 시기이었다.

1994 2002년 동안에는 성공적인 프로젝트 경험 을 바탕으로 $\mathrm{EPC}$ 프로젝트가 기술적 위험이 없다는 점을 고객에게 입증하였다. 미국은 1996년에 $\mathrm{M \& V}$ 가이드라인 개발을 처음 시도하였으며, 1997년 IPMVP의 개발을 계기로 미국은 2002년 M\&V 가이 드라인을 보완하면서 $\mathrm{ESCO}$ 프로젝트의 에너지절약 성과를 확인하기 위한 표준방법이 적극 활용되었다.

Table 1. Summary of IPMVP M\&V

\begin{tabular}{|c|c|c|}
\hline 옵션 & $\mathrm{M} \& \mathrm{~V}$ 방법 개요 & 에너지절약량의 산정방식 \\
\hline $\begin{array}{l}\text { 옵션 } \mathrm{A} \\
\text { (부분 측정, } \\
\text { 기기별 측정) }\end{array}$ & $\begin{array}{l}\text { •에너지절약대책 장소의 에너지소비량을 측정 } \\
\text { •측정기간은 단기 또는 연속 } \\
\text { •부분 측정은 모두 파라메타를 측정할 필요 없음 } \\
\text { •상정치 이용시 에러가 없는 경우 한정적 사용 }\end{array}$ & $\begin{array}{l}\text { •단기 측정결과와 상정 치로부터 } \\
\text { 공학적 계산에 의해 산정 }\end{array}$ \\
\hline $\begin{array}{c}\text { 옵션 } \mathrm{B} \\
\text { (기기별 측정) }\end{array}$ & $\begin{array}{l}\text { - 에너지절약대책 장소의 에너지소비량을 측정 } \\
\text { •단기 또는 성과계약기간 중 연속 측정 }\end{array}$ & -단기, 장기측정결과로 공학적 계산 \\
\hline $\begin{array}{c}\text { 옵션 } \mathrm{C} \\
\text { (시설 전체의 측정) }\end{array}$ & $\begin{array}{l}\text { •시설 전체의 에너지소비량 측정 } \\
\text { •단기 또는 성과계약기간 중 연속 측정 }\end{array}$ & $\begin{array}{l}\text { •시설 전체의 전력, 가스량 측정기의 } \\
\text { 데이터를 이용한 회귀분석 실시 }\end{array}$ \\
\hline $\begin{array}{c}\text { 옵션D } \\
\text { (시뮬레이션에 의한 } \\
\text { 보정) }\end{array}$ & $\begin{array}{l}\text { •에너지절약대책 도입 장소 또는 시설 전체의 } \\
\text { 에너지소비량에 대한 시뮬레이션 계산 } \\
\text { •시뮬레이션 모형은 실제 에너지절약량의 측정치로 데모 } \\
\text { 테스트 실시 } \\
\text { •시뮬레이션에 의한 보정에 대해서는 경험 필요 }\end{array}$ & $\begin{array}{l}\text { •시간별 또는 월별 검증치, 또는 } \\
\text { 측정치를 이용한 시뮬레이션 실시 }\end{array}$ \\
\hline
\end{tabular}


2003년 이후 현재까지 다양한 EPC 시장 주도기업의 출현으로 $\mathrm{ESCO}$ 프로젝트에 대한 운영 및 유지 관리 $(\mathrm{O} \& \mathrm{M})$ 비용의 절감, 온실가스 배출 감축, 전력시스 템 용량 감축 등을 감안한 측정기법이 요청되는 시기 로, 2008 년에 $\mathrm{M} \& \mathrm{~V}$ 가이드라인의 개정작업 및 보완 을 완료하였다.

\section{3-2. 미국 에너지관리프로그램의 $\mathrm{M} \& \mathrm{~V}$ 가이드라인 개요 [7,8] \\ 미국 에너지관리프로그램(Federal Management} Program, FEMP)의 M\&V 가이드라인은 연방정부의 건물 에너지절약 개수 성과계약을 시행할 때 지침서 용으로 작성되었다. 특히, 연방 정부 건물의 에너지비 용절감을 위해 실시하는 에너지절약 개수 프로젝트에 있어서 연방 정부기관의 담당자용으로 작성되었다. 실제로는 연방정부의 건물에 국한하지 않고 민간건물 을 대상으로 에너지절약 개수 성과계약을 할 때 가이 드라인으로 사용되고 있다.

FEMP의 M\&V 가이드라인은 1996 년에 최초로 가 이드라인이 작성되어, 그 후 2002년 7월과 2008년 4 월에 개정판이 작성되었다. $\mathrm{FEMP}$ 의 $\mathrm{M} \& \mathrm{~V}$ 가이드라 인이 포함된 항목은 아래와 같으며, IMPVP와 비교 할 때 옵션(option)별로 적용 가능한 에너지절약 대책 에 대해서 구체적인 사항을 설명하고 있는 것이 특징 이다.

즉 1) 옵션별 $\mathrm{M} \& \mathrm{~V}$ 방법의 개요 : 옵션 종류 $\mathrm{A}$ $\mathrm{D}$, 옵션별 적용사례, 2) 절수관련 대책의 $\mathrm{M} \& \mathrm{~V}$ 방법 : 건물 신축, 운전, 관리방법, 열병합발전, 신재생에너 지, 3) 성과계약에 있어서의 책임분담 및 위험배분, 4) 간이 $\mathrm{M} \& \mathrm{~V}$ 가이드라인을 작성(점검 리스트, 각 옵션의 개요), 5) 일반적인 에너지절약 대책의 최적옵 션 가이드라인, 6) 에너지절약 대책 이외의 에너지대 책의 가이드라인 추가, 즉 건물의 신설, 운전, 관리방 법 및 열병합발전 등에 관해 설명되어 있다. 특히 옵 션 $\mathrm{A}$ 에 있어서 모든 변수에 대해 신뢰할 수 있는 데 이터가 있으면 추정치를 이용해도 무방하며, 이 부분 이 IPMVP와 다른 점이라고 할 수 있다.

\section{3-3. 기본적인 $\mathrm{M} \& \mathrm{~V}$ 절차 $[7,8]$}

건물의 에너지절약량은 일반적으로 에너지절약 개 수 전·후에 대한 에너지소비량을 비교함으로써 파악 할 수 있다. 여기서 에너지절약 개수 전의 에너지소
비량을 베이스라인, 개수 후의 에너지소비량을 개수 후 에너지소비량 또는 $\mathrm{EPC}$ 계약기간 중 에너지소비 량으로 지칭한다. 보정은 베이스라인 설정 시와 성과 계약기간의 기후조건, 가동율의 차이에 의한 보정을 의미한다.

에너지절약량 $=$ 베이스라인 에너지소비량(보정치) - 개수 후 에너지소비량

$\mathrm{M} \& \mathrm{~V}$ 는 $\mathrm{EPC}$ 를 실시하는 사업자가 에너지절약성 과를 적절한 수준에서 파악한 결과에 대해서 담당자 가 확인하는 것이어야 한다. $\mathrm{EPC}$ 프로젝트를 실시하 기 위한 필요사항은 1) 성과계약에서 발생되는 문제 점으로 정부기관 또는 $\mathrm{ESCO}$ 사업자가 리스크로서 부담해야 하는 사항에 관한 이해, 2) 프로젝트의 $\mathrm{M} \& \mathrm{~V}$ 계획 수립, 3) 베이스라인 상황과 에너지절약 대책에 의한 에너지절약성과 검증 관련 문서화, 4) $\mathrm{M} \& \mathrm{~V}$ 방법의 4종류 옵션에 의해 절감성과 결정에 관 한 이해 등과 같다.

정부기관과 $\mathrm{ESCO}$ 사업자 간 책임분담의 배분에 영향을 주는 계약상의 문제점은 자금, 운영 및 성능 측면에서 제기되고 있다. 특히 자금 측면의 요소가 중요하기 때문에 자금 측면에서는 물가, 에너지가격, 건설비용, $\mathrm{M} \& \mathrm{~V}$ 비용 등의 요인을 살펴볼 필요가 있 다.

에너지절약 대책 도입에 의한 $\mathrm{ESCO}$ 사업 계약기간 에 있어서 절감성과의 추계작업은 일반적으로 정기적 인 실시방안을 고려해야 한다. 이때의 기본적인 조건 은 다음과 같다. 즉, 베이스라인에 대한 정확한 정의 정립, 개별 기기/시스템의 설치 완비, 기기/시스템이 사 양에 맞는 성능 발휘, 기기/시스템이 예상한 대로 절감 량을 얻을 수 있는 능력의 유지 등을 들 수 있다.

이 때에 베이스라인 에너지소비량, 개수 후 에너지 소비량, 에너지절약성과는 이하의 $\mathrm{M} \& \mathrm{~V}$ 방법으로 확 정한다. 즉 엔지니어링 계산, 측정 및 모니터링·전력. 가스-수도미터 수치의 분석, 컴퓨터 시뮬레이션을 활 용할 수 있다.

\section{3-4. $\mathrm{M} \& \mathrm{~V}$ 옵션 $[7,8]$}

미국 FEMP에서의 $\mathrm{M} \& \mathrm{~V}$ 옵션은 IPMVP에서의 정의와 동일한 4 가지 종류의 유형으로 분류된다. 각 옵션별 개요, 에너지절약량의 산정방법, $\mathrm{M} \& \mathrm{~V}$ 비용 은 아래 표와 같다. 또한 $\mathrm{M} \& \mathrm{~V}$ 비용은 프로젝트 비 
용 전체에서 차지하는 비율을 나타낸다.

\section{3-5. $\mathrm{M} \& \mathrm{~V}$ 계획의 작성 $[7,8]$}

$\mathrm{M} \& \mathrm{~V}$ 계획을 작성할 경우 필요한 항목은 프로젝 트 개요, 에너지절약 비용, $\mathrm{M} \& \mathrm{~V}$ 계획 및 $\mathrm{M} \& \mathrm{~V}$ 방 법 등을 포함하여 정리한다. 먼저, 1) 프로젝트 개요 : 프로젝트의 목표, 대상시설의 특징, 에너지절약 대 책의 개요(절감방법을 포함해 언급), 2) 에너지절약 비용 : 에너지절약 대책에 의한 절감량 예측치, $\mathrm{M} \& \mathrm{~V}$ 비용의 견적, 3) 스케줄 : 기기설치 스케줄, 4) 보고 : 원데이터는 전력소비량, 15 분치 등으로 작성. 종합 데이터 서식은 월별 $\mathrm{kWh}$ 등으로 작성. 보고서는 연 간 1회씩 제출, 5) $\mathrm{M \& V}$ 방법 : 정확도는 에너지절약 량 $\pm 10 \%$ 오차범위로, 적용 옵션은 옵션 $\mathrm{A}, \mathrm{B}, \mathrm{C}, \mathrm{D}$ 중 선택하여 $\mathrm{M \& V}$ 의 책임과 관련한 $\mathrm{ESCO}$ 사업자가 $\mathrm{M} \& \mathrm{~V}$ 보고 책임 등에 관해 작성하도록 권고하고 있 다.

보고서의 작성은 $\mathrm{M} \& \mathrm{~V}$ 계획의 수립에 관한 최종 적인 내용을 포함한다. 보고서의 표준적인 서식에 대 해서는 FEMP 가이드라인에 첨부되어 있으나, 에너 지절약 대책 종류별 제출 데이터의 기간종류에 따라 달라진다. 보고서의 작성양식 형태 이외에도 측정치 의 원래 데이터 등을 포함하여 제출해야 한다.

4. 일본의 에너지절약성과 $\mathrm{M} \& \mathrm{~V}$ 가이드라인 관련 주요내용

4-1. 일본 $\mathrm{ESCO} \mathrm{M \& V}$ 가이드라인 작성배경 [3-5] 일본에서는 1996년 $\mathrm{ESCO}$ 도입을 위한 검토가 시
작된 이후, 1998 년 4건의 사업을 계약되면서 $\mathrm{ESCO}$ 사업이 시작되었다. 일본에서는 에너지절약 보증계약 에 기반한 $\mathrm{ESCO}$ 사업이 추진되었기 때문에 자국의 여건에 적합한 $\mathrm{M \& V}$ 가이드라인을 개발할 필요성이 제기되었다. 이에 따라 1999년부터 업무시설을 대상 으로 에너지소비에 관한 측정 조사를 실시였다.

1999년부터 업무시설을 중심으로 에너지소비의 측 정 조사를 실시하여, 2002 년에 $\mathrm{M \& V}$ 방법의 가이드 라인을 처음 개발하였다. 이후 $\mathrm{ESCO}$ 사업에 대한 에 너지절약성, 경제성, $\mathrm{M} \& \mathrm{~V}$ 방법을 평가하는 동시에 표준계약서 작성에도 활용되었다. 2005년에는 $\mathrm{M \& V}$ 방법의 가이드라인을 갱신하였다. 이러한 일본의 가 이드라인은 $\mathrm{ESCO}$ 기업의 능력개발 목적으로 미국의 $\mathrm{M} \& \mathrm{~V}$ 방법을 기본적으로 참조하여 개발한 것으로 알려지고 있다.

\section{4-2. 일본의 에너지절약성과 $\mathrm{M} \& \mathrm{~V}[3,5]$}

일본에서는 $\mathrm{ESCO}$ 사업에 대한 측정과 검증에 있 어서 $\mathrm{ESCO}$ 사업자와 위탁사업자 간의 문제를 발생 시키지 않기 위해 과학적이고 합리적인 방법에 의한 $\mathrm{M} \& \mathrm{~V}$ 를 수행하고 있다. 측정과 검증목적은 1) $\mathrm{ESCO}$ 사업에 지불되는 금액을 명확히 산출, 2) 설비를 효율 적으로 가동시키기 위한 것이며, 3) $\mathrm{ESCO}$ 사업에 의 한 절감량에 대한 보증의 신뢰성을 높이는 데 있다. 에너지절약성과의 평가는 에너지절약 개선공사가 이행되지 않은 경우의 에너지소비량을 베이스라인으 로 추정한 값과 실제의 에너지소비량을 비교한다. 이 비교에서 베이스라인이 변동될 수도 있다. 이를 정확 히 파악하기 위해서는 측정을 포함한 충분한 기간의

Table 2. Summary of US M\&V

\begin{tabular}{|c|c|c|c|}
\hline 옵션 & $\mathrm{M} \& \mathrm{~V}$ 방법 개요 & 에너지절약량 산정방법 & $\mathrm{M} \& \mathrm{~V}$ 비용 \\
\hline $\begin{array}{c}\text { 옵션 } \mathrm{A} \\
\text { (추정치 및 계산치) }\end{array}$ & $\begin{array}{l}\text { •추정치, 측정치를 사용 } \\
\text { •측정은 단독, 단기로 구성요소 또는 시스템 } \\
\text { 전체를 측정함 } \\
\text { •추정치는 과거의 실적치, 카탈로그치를 사용 }\end{array}$ & $\begin{array}{l}\text { - 엔지니어링계산 } \\
\text { 구성요소, 시스템 } \\
\text { 전체모형 }\end{array}$ & $\begin{array}{l}\text { - 측정 장소의 수에 } \\
\text { 따라 1 3\% }\end{array}$ \\
\hline $\begin{array}{l}\text { 옵션 B } \\
\text { (계산치) }\end{array}$ & $\begin{array}{l}\text { •변동요인이 없다고 가정할 경우 단독, } \\
\text { 단기측정을 기본으로 함 } \\
\text { •변동요인이 있는 경우는 연속측정을 실시 }\end{array}$ & $\begin{array}{l}\text { - 엔지니어링계산 } \\
\text { 구성요소, 시스템 } \\
\text { 전체모형 }\end{array}$ & $\begin{array}{l}\text { •측정 장소의 수, } \\
\text { 측정기간에 따라 } \\
3 \sim 15 \%\end{array}$ \\
\hline $\begin{array}{c}\text { 옵션 C } \\
\text { (에너지사용량 } \\
\text { 검침치 분석) }\end{array}$ & $\begin{array}{l}\text {-장기간의 건물 전체에 대한 전력·가스거래 } \\
\text { 미터, 시설단위, 전기계량기 수치를 사용 }\end{array}$ & $\begin{array}{l}\text {-에너지사용량 검침치를 } \\
\text { 이용한 회귀분석 }\end{array}$ & $\begin{array}{l}\text {-검침치 분석의 } \\
\text { 복잡화에 따라 } \\
1 \sim 10 \%\end{array}$ \\
\hline $\begin{array}{c}\text { 옵션 D } \\
\text { (시뮬레이션) }\end{array}$ & $\begin{array}{l}\text { •컴퓨터 시뮬레이션에 의한 데이터 사용 } \\
\text { •단독, 단기, 장기 측정치 사용 } \\
\text { •건물 전체 에너지사용량의 장기 검침치 사용 }\end{array}$ & $\begin{array}{l}\text { •컴퓨터 시뮬레이션으로 } \\
\text { 건물 전체 데이터, 용도별 } \\
\text { 데이터에 의해 보정 }\end{array}$ & $\begin{array}{l}\text { •시스템 모형에 } \\
\text { 따라 3 15\% }\end{array}$ \\
\hline
\end{tabular}


데이터 수집 작업이 필요하며, 적절한 에너지절약성 과를 추정하는 방법을 고객과 $\mathrm{ESCO}$ 사업자가 비용 측면까지 고려하여 합의를 도출하는 것이 중요하다.

일반적인 $\mathrm{M} \& \mathrm{~V}$ 시행 순서를 보면, 1) $\mathrm{ESCO}$ 계약 을 추진하기 위한 일반적인 $\mathrm{M} \& \mathrm{~V}$ 방법의 검토, 2) 에너지절약량 및 비용절감액 계산, 3) 에너지절약 개 선계획의 계약 및 $\mathrm{M} \& \mathrm{~V}$ 계획의 합의, 4) 데이터 수 집, 5) 베이스라인의 에너지소비량 설정, 6) 설비설치 후의 에너지절감량 추정, 7) 계약기간 중의 에너지절 감량 추정, 8 ) 지불금 결정 등의 절차로 진행된다.

\section{4-3. $\mathrm{M} \& \mathrm{~V}$ 의 방법 [3,5]}

$\mathrm{M} \& \mathrm{~V}$ 방법은 IPMVP에서 소개된 옵션(option)에 따른 방법으로 크게 A.B.C.D의 4가지로 구분되며, 옵 션별로 측정방법 및 에너지소비량 추정방법이 다르 다. 각각 옵션의 특징을 크게 두 가지로 나누면 비교 적 간단한 에너지이용에 따른 추정과 복잡한 에너지 이용에 따른 추정으로 나뉘며, 옵션 $\mathrm{A}$ 와 $\mathrm{B}$ 가 전자에 해당되며 옵션 $\mathrm{C}$ 와 $\mathrm{D}$ 가 후자에 해당된다고 볼 수 있 다.

비교적 간단한 에너지이용에 따른 추정방법에서
측정대상은 기기의 정격 입력치, 운전시간, 카탈로그 수치 및 단시간의 실측치가 사용된다. 반면에 복잡한 에너지이용에 따른 추정방법은 기기의 정격 규격치, 운전시간, 부하율 및 월별 실측치 등의 장기 측정치 에 의해 입지환경 조건 등이 사용된다. 옵션을 선택 하는데 있어서 간단한 판단기준은 첫째로 에너지절약 방법별로 평가가 가능한지의 여부 판단, 둘째로 부하 가 안정적인가에 대한 판단, 셋째로 운전모드가 안정 적인가에 대한 판단, 마지막으로 경제적 부담의 허용 범위가 어떤지에 대한 판단에 의해 결정할 수 있다.

\section{4-4. $\mathrm{M} \& \mathrm{~V}$ 결과의 보고 [3,5]}

$\mathrm{ESCO}$ 사업자가 고객에게 에너지절약량을 보고하 기 위한 보고서에 포함해야 될 사항은 주로 $\mathrm{M \& V}$ 방 법 및 설명, 에너지절약량 산출식, 계산의 전제 및 에 너지절약량 산출결과 등이 중요하게 제시되고 있다. 이러한 $\mathrm{M} \& \mathrm{~V}$ 보고서에서는 $\mathrm{M} \& \mathrm{~V}$ 결과와 그 근거가 실증적으로 명확히 기재되어 있어야 한다.

이와 같은 $\mathrm{M \& V}$ 보고서에는 1) 대책 전.후의 기기 리스트, 2) 기기의 상황을 나타내는 사진 및 비디오 등에 의한 기록, 3 ) 기기의 제조업체명, 제조번호, 명

Table 3. Summary of JAPAN M\&V

\begin{tabular}{|c|c|c|c|c|}
\hline 옵션 & 옵션 A & 옵션 B & 옵션 C & 옵션 D \\
\hline 적용대상 & -특정 기기의 교환 등 & $\begin{array}{l}\text { •특정 장치, 부분적인 } \\
\text { 시스템 개수 }\end{array}$ & $\begin{array}{l}\text { •시설 전체의 } \\
\text { 에너지소비량 평가 }\end{array}$ & $\begin{array}{l}\text {-시설 전체의 } \\
\text { 에너지소비량 평가 }\end{array}$ \\
\hline 특징 & $\begin{array}{l}\text { •도입된 방법별 평가 } \\
\text { •시스템 부하변동이 작음 } \\
\text {-시스템 연간 운전시간이 일정 } \\
\text { •변환기기 효율에 의해 절감량 } \\
\text { 보증 }\end{array}$ & $\begin{array}{l}\text { •도입된 방법별 평가 } \\
\text { •시스템 부하변동이 큼 } \\
\text { •시스템의 연간 } \\
\text { 가동시간이 변화 }\end{array}$ & $\begin{array}{l}\text { •도입된 방법을 } \\
\text { 시스템 및 건물 전체로 } \\
\text { 평가 } \\
\text { •통계학적 방법 } \\
\text { 이용이 많음 }\end{array}$ & $\begin{array}{l}\text { •도입된 방법을 } \\
\text { 시스템 및 건물 } \\
\text { 전체로 평가 }\end{array}$ \\
\hline \multirow{2}{*}{$\begin{array}{l}\text { 베이스 } \\
\text { 라인 }\end{array}$} & $\begin{array}{l}\text {-기술자료 등의 정격 } \\
\text { 에너지소비량 판명시 측정을 } \\
\text { 안할 수 있음 } \\
\text { •측정을 하는 경우 현장 측정, } \\
\text { 단기 측정 실시 }\end{array}$ & $\begin{array}{l}\text { •기기별 소비량을 단기 } \\
\text { 측정 } \\
\text { •계약기간동안 평가를 } \\
\text { 지속적으로 하는 } \\
\text { 경우도 있음 }\end{array}$ & $\begin{array}{l}\text { •기기별 측정은 하지 } \\
\text { 않음(단, 부분 측정) } \\
\text { •기존 측정 데이터를 } \\
\text { 이용해 이론적인 } \\
\text { 에너지소비량을 추정 }\end{array}$ & $\begin{array}{l}\text {-기기별 측정은 } \\
\text { 하지 않음(단, } \\
\text { 부분적인 측정을 } \\
\text { 하기도 함) }\end{array}$ \\
\hline & $\begin{array}{l}\text { •개수 전 기기성능에 } \\
\text { 운전시간을 곱해 산물 } \\
\text { •측정한 기기성능에 연간 } \\
\text { 운전시간을 곱하여 구함 }\end{array}$ & $\begin{array}{l}\text { •측정 결과를 토대로 } \\
\text { 소비량을 산정 } \\
\text { (변동요인의 관계를 } \\
\text { 수식화도 필요) }\end{array}$ & $\begin{array}{l}\text {-개수 전의 운전실적 } \\
\text { 데이터를 이용하여 } \\
\text { 소비량 추정 식을 도출 }\end{array}$ & $\begin{array}{l}\text { - 개수 전의 } \\
\text { 운전실적 데이터에 } \\
\text { 의해 시뮬레이션 } \\
\text { 계수를 조절 }\end{array}$ \\
\hline $\begin{array}{c}\text { 개수 후 } \\
\text { 에너지 } \\
\text { 소비량 파악 }\end{array}$ & $\begin{array}{l}\text { •측정을 하지 않는 경우가 } \\
\text { 많음. } \\
\text { •단기 측정을 하고 기기 } \\
\text { 특성이 변화를 확인 }\end{array}$ & $\begin{array}{l}\text { •단·중기 측정으로 } \\
\text { 에너지소비량 추정 } \\
\text { •장기 측정하는 경우도 } \\
\text { 있음 }\end{array}$ & $\begin{array}{l}\text { •통계처리로 파악 } \\
\text { •부분적인 단기·장기 } \\
\text { 측정을 하는 경우도 } \\
\text { 있음 }\end{array}$ & $\begin{array}{l}\text { •복잡한 통계처리 } \\
\text { •시뮬레이션의 } \\
\text { 보정계수를 산출 }\end{array}$ \\
\hline $\begin{array}{l}\text { 개수 후 } \\
\text { 검증 }\end{array}$ & \multicolumn{4}{|c|}{ •베이스라인과 개수 후의 소비량(실측/추정치) 산출 } \\
\hline
\end{tabular}


Table 4. Comparison of major M\&V summary

\begin{tabular}{|c|c|c|c|}
\hline 구분 & IPMVP & 미국 & 일본 \\
\hline 목적 & $\begin{array}{l}\text {-에너지절약개선 실시자에 대해 } \\
\text { 에너지절약대책의 도입 성과를 } \\
\text { 정량화하기 위한 가이드라인 제시 }\end{array}$ & $\begin{array}{l}\text { 연방정부 건물에 대한 } \\
\text { 에너지절약 개수의 성과 계약 시 } \\
\text { 가이드라인으로 활용 } \\
\text { •민간부문의 건물을 대상으로 } \\
\text { 하는 에너지절약 개수의 성과계약 } \\
\text { 시 가이드라인으로 사용 }\end{array}$ & $\begin{array}{l}\text { ESCO 사업에 의해 지불되는 } \\
\text { 금액을 명확히 하고, } \\
\text { 에너지절약설비의 효율적인 가동 } \\
\text { 유도 } \\
\text { •ESCO 사업에 의한 } \\
\text { 에너지절감량 보증의 신뢰성 제고 }\end{array}$ \\
\hline 주요내용 & $\begin{array}{l}\text { 1. 옵션별 } \mathrm{M \& V} \text { 방법 } \\
\text { - 옵션종류: } \mathrm{A} \sim \mathrm{D} \\
\text { - } \mathrm{M} \& \mathrm{~V} \text { 방법의 개요 } \\
\text { 2. 일반적인 사항 } \\
\text { - 에너지절약성과 변동요인 } \\
\text { - 최저에너지소비효율 } \\
\text { - 에너지가격 } \\
\text { - 베이스라인의 설정 } \\
\text { - 기상 데이터 } \\
\text { 3. 측정에 관한 사항 } \\
\text { - 검침 데이터의 사용 } \\
\text { - 전력부하 } \\
\text { - 측정관련 기술 } \\
\text { - 교정 } \\
\text { - 에너지관리시스템 데이터이용 } \\
\text { 4. 옵션별 적용사례 }\end{array}$ & $\begin{array}{l}\text { 1. 옵션별 } \mathrm{M} \& \mathrm{~V} \text { 개요 } \\
\text { - 옵션 } \mathrm{A} \\
\text { - 옵션 } \mathrm{B} \\
\text { - 옵션 } \mathrm{C} \\
\text { - 옵션 } \mathrm{D} \\
\text { - 옵션별 적용사례 } \\
\text { 2. 절수관련대책의 } \mathrm{M} \& \mathrm{~V} \text { 방법 } \\
\text { 3. 에너지절약대책 } \mathrm{M} \& \mathrm{~V} \text { 방법 } \\
\text { - 건물의 신축 } \\
\text { - 운전 및 관리방법 } \\
\text { - 열병합방법 } \\
\text { - 신에너지 }\end{array}$ & $\begin{array}{l}\text { 1. } \mathrm{M} \& \mathrm{~V} \text { 방법 개요 } \\
\text { 2. 일반적 } \mathrm{M} \& \mathrm{~V} \text { 순서 } \\
\text { 3. 옵셥별 } \mathrm{M} \& \mathrm{~V} \text { 방법 선택 } \\
\text { - 옵션 } \mathrm{A} \\
\text { - 옵션 } \mathrm{B} \\
\text { - 옵션 } \mathrm{C} \\
\text { - 옵션 } \mathrm{D} \\
\text { 4. } \mathrm{M} \& \mathrm{~V} \text { 결과의 보고 } \\
\text { - 보고서 } \\
\text { - 첨부서류 } \\
\text { 5. } \mathrm{M} \& \mathrm{~V} \text { 방법의 설비별 선택 } \\
\text { 요약표 제시 }\end{array}$ \\
\hline 작성년도 & 1997 & 1996 & 2002 \\
\hline 갱신년도 & 2002,2007 & 2002,2008 & 2005 \\
\hline 상이점 & $\begin{array}{l}\text { •옵션 } \mathrm{A} \text { 에 최소 한 개 이상측정 } \\
\text { 실시, 가동시간 등 변수를 측정 } \\
\text { 또는 에너지절약량 자체에 대한 } \\
\text { 직접 추계치 이용 금지 } \\
\text { •표준양식 및 이에 대한 작성요령 } \\
\text { 미비 }\end{array}$ & $\begin{array}{l}\text { •옵션 } \mathrm{A} \text { 에 있어서 모든 변수에 } \\
\text { 대해 신뢰성이 있는 데이터인 } \\
\text { 경우 상정치를 이용 가능. 따라서 } \\
\text { 옵션 } \mathrm{A} \text { 에서 실측조사는 불필요 } \\
\text {-개략적 보고서 양식 및 이에 } \\
\text { 대한 작성법 소개 }\end{array}$ & $\begin{array}{l}\text { •표준양식 및 이에 대한 } \\
\text { 작성요령이 미비 }\end{array}$ \\
\hline
\end{tabular}

판기록, 4) 조명의 개선을 검토하는 경우는 기준 및 설치 후 조명 광도 수준의 측정결과, 5) $\mathrm{M} \& \mathrm{~V}$ 에 활 용된 데이터의 기초통계량 및 주요 설정치 등 보충적 인 자료가 추가되어야 한다.

\section{5. 주요국의 $\mathrm{ESCO} \mathrm{M \& V}$ 적용관련 시사점}

국내에서도 $\mathrm{ESCO}$ 의 에너지절약성과에 대한 $\mathrm{M} \& \mathrm{~V}$ 가 중요한 과제로 부각되고 있는 시점에서 선 진국의 $\mathrm{M} \& \mathrm{~V}$ 적용사례에 대해 파악하였다. IPMVP 는 1997년 처음 공표된 이래 2002년에 IPMVP에 대 한 전반적 보완 작업, 2007년 4월에는 $\mathrm{M \& V}$ 개념, 에너지절약관련 보고, 에너지절약량 산출 등에 관한 내용 추가 및 전반적인 내용을 보완하였다.

미국의 $\mathrm{ESCO}$ 모니터링 및 $\mathrm{M} \& \mathrm{~V}$ 방법에 대한 적 용은 1996년 M\&V 가이드라인을 처음 자체 개발 및
1997년 IPMVP의 개발을 계기로, ESCO 사업에 대 해 정착되기 시작한 것으로 파악된다. 일본의 경우에 는 $\mathrm{ESCO}$ 기업에 대한 $\mathrm{M} \& \mathrm{~V}$ 방법의 보급을 목적으 로 일본 여건에 적합한 가이드라인을 개발할 필요성 이 제기됨에 따라, 1999년 업무시설을 중심으로 에너 지소비의 측정 조사를 실시하여 2002년에 $\mathrm{M} \& \mathrm{~V}$ 방 법에 대한 가이드라인을 개발하였다.

이와 같이 주요국에서 $\mathrm{ESCO}$ 사업의 에너지절약성 과에 대한 정량화 작업을 위한 가이드라인, 에너지절 감량에 대한 보증의 신뢰성 제고 등을 목적으로 $\mathrm{M} \& \mathrm{~V}$ 방법에 대한 가이드라인이 적용되고 있다. 공 통적으로 옵션별 $\mathrm{M} \& \mathrm{~V}$ 방법의 개요, 일반적 $\mathrm{M} \& \mathrm{~V}$ 의 시행과정, 옵션별 $\mathrm{M} \& \mathrm{~V}$ 방법의 선택 및 적용내용 등 에 대해 설명하고 있다.

국내에서도 $\mathrm{ESCO}$ 산업에 대한 성과보증방식 위주 의 역량강화를 촉진하기 위해 에너지절약성과에 대한 
$\mathrm{M} \& \mathrm{~V}$ 가 중요한 과제로 부각되고 있는 시점에서 적 합한 $\mathrm{M \& V}$ 적용방안 제시가 요청되고 있다. 에너지 사용자와 $\mathrm{ESCO}$ 기업 간의 에너지절약성과 보증계약 체결에 의한 에너지절약설치로 발생되는 에너지절감 량을 측정.평가하는 방안을 제공하는 것이 무엇보다 중요하다고 할 수 있다.

따라서 국내 $\mathrm{ESCO}$ 업계에 적합한 $\mathrm{M \& V}$ 적용방향 을 설정하고 이에 따른 $\mathrm{M} \& \mathrm{~V}$ 절차 및 유의사항과 옵 션별 $\mathrm{M} \& \mathrm{~V}$ 선택방법 제시, $\mathrm{M} \& \mathrm{~V}$ 를 위한 표준양식과 작성방법에 관한 대안 강구가 요청된다. 향후 연구과 제로 앞서 파악한 주요국의 $\mathrm{M} \& \mathrm{~V}$ 사례조사 결과를 바탕으로 국내 $\mathrm{ESCO}$ 여건을 감안한 $\mathrm{M \& V}$ 작성 가 이드라인 작성방안이 마련될 필요가 있다.

\section{References}

1. 지식경제부, 에너지절약의 산업화를 위한 $\mathrm{ESCO}$ 산업 활성화 방안, 보도자료, 2010.10.20

2. 지식경제부, 에너지절약전문기업 관리규정, 공 고 제2013-40호, 2013.2.25

3. 省エネルギーセンター，エネルギー使用合理化 事業者支援事業調查研究事業，新エネルギー 産業技術総合開発機構, 2003

4. 村越千春 외, “米国㧍よびアジア諸国における $\mathrm{ESCO}$ 事業の実態と今後の普及促進策に関す る研究, ”都市·建築学研究, “九州大学大学院 人間環境学研究院，第14号，pp. 119-129, 2008.7

5. 村越千春 외, “我加国に扔汁るESCO事業の発 展経緯と事業特性に関方多研究,”都市·建築 学研究, 九州大学大学院 人間環境学研究院 紀要，第12号，pp. 91-101，2007.7

6. Efficiency Valuation Organization, International Performance Measurement and Verfication Pro tocol(IPMVP), 2007

7. FEMP(Federal Management Program, FEMP), US DOE, M\&V Guidelines : Measurement and Verification for Federal Energy Projects, Version 3.0, 2008

8. FEMP, US DOE, M\&V Guidelines : Measurement \& Verification for Federal Energy Projects, Ver 2.2, 2 